\title{
Platinum derivatives: generic brands vs. original, in vitro tests
}

\section{Derivaţii de platină: medicamente generice vs. originale, teste in vitro}

\author{
Sînziana Cetean ${ }^{1,2^{*}}$, Călin Căinap ${ }^{1,2}$, Olga Soriţău ${ }^{2}$, Corina Tatomir², Piroska \\ Virag $^{2}$, Adriana Hangan ${ }^{1}$, Luminiţa Oprean ${ }^{1}$, Radu Oprean ${ }^{1}$ \\ 1. University of Medicine and Pharmacy "Iuliu Haţieganu” Cluj-Napoca \\ 2. The Oncology Institute "Prof. Dr. Ion Chiricuţă" Cluj-Napoca
}

\begin{abstract}
The entry of the generic drugs on the market was an impressive development of the pharmaceutical industry and due to their lower prices also a decrease in the cost price for the treatment of patients. The difference in price (sometimes even 50\%) between generics and original and different response to therapy sometimes raised serious questions related to their therapeutic equivalence. The scientific community is increasingly interested in this aspect, with studies (in vitro and on patients) demonstrated statistically significant differences in terms of differences generic / original drug. In this context, the aim of our study was to assess the in vitro cytotoxic activity of oxaliplatin (original and generic drug) on DLD-1 cell lines, HT-29, and carboplatin cytotoxic activity (and the reference molecule from Santa Cruz Biotechnology) on cell line A2780. Cell viability was evaluated using the MTT assay.

Regarding the cell line DLD-1, IC50 values of generics was lower than the original after exposure for 24 hours to oxaliplatin but after 48 hours of exposure were not statistically significant differences. HT-29 line has a higher resistance to chemotherapy compared with oxaliplatin, the IC 50 values after 48 hours of exposure are higher than those for the line DLD-1. IC50 values are confirmed by morphological analysis of cells. Regarding carboplatin were not recorded statistically significant differences between the two generic drugs tested.

Although other studies reported differences between generic and branded drugs in terms of hypersensibility reactions, adverse effects and efficacity, we cannot extrapolate our findings to the patients. Further studies on patients are neeeded for a better evaluation of the efficacity of generic vs. original drugs.
\end{abstract}

Keywords: Oxaliplatin, generic vs original, cancer, carboplatin

\section{Rezumat}

Intrarea pe piaţă a medicamentelor generice a reprezentat o dezvoltare impresionantă a industriei farmaceutice şi de asemenea o scădere a preţului de cost pentru tratamentul bolnavilor datorită preţurilor mai mici a acestora. Diferenţa de preţ (uneori chiar de 50\%) între medicamentele generice şi originale precum şi răspunsul uneori diferit la terapie a ridicat serioase semne de intrebare legat de echivalența terapeutică a acestora. Comunitatea ştiințifică este din ce în ce mai interesată de acest aspect, existând studii (in vitro dar şi pe pacienţi) care au

*Corresponding author: Sînziana Cetean, University of Medicine and Pharmacy Cluj-Napoca Cluj-Napoca, Romania, e-mail: cetean.sinziana@umfcluj.ro 
demonstrat diferenţe statistic semnificative în ceea ce priveşte diferenţele medicament generic/original. In acest context, studiul nostru şi-a propus evaluarea citotoxică in vitro a oxaliplatinului (medicament original şi generice) pe liniile celulare DLD-1, HT-29, şi a carboplatinului (şi molecula de referinţă achiziţionată de la Santa Cruz Biotechnology) pe linia celulară A2780. Viabilitatea celulară a fost testată folosind testul MTT.

In ceea ce priveşte linia DLD-1, valoarea IC50 a medicamentelor generice a fost mai mică comparativ cu originalul după expunerea timp de 24 de ore la oxaliplatin însă după 48 de ore de expunere nu au fost diferenţe statistic semnificative. Linia HT-29 prezintă o rezistență mai mare la chimioterapia cu oxaliplatin, valorile IC50 după 48 de ore de expunere sunt mai mari comparativ cu cele pentru linia DLD-1. Valorile IC50 sunt confirmate şi de analiza morfologică a celulelor. In ceea ce priveşte carboplatinul, nu au fost înregistrate diferenţe statistic semnificative intre cele două medicamente generice testate.

Deşi unele studii au arătat diferenţe între medicamentele generice şi originale în ceea ce priveşte apariţia reacţiilor adverse, reacţiilor de hipersensibilitate şi a eficacităţii, nu putem extrapola rezultatele noastre la rezultatele din clinică. Este nevoie de investigaţii suplimentare pentru a stabili dacă există o diferenţă între medicamente şi în ce măsură acestea afectează evoluţia bolii.

Cuvinte cheie: Oxaliplatin, generic vs original, cancer, carboplatin

Received: $8^{\text {th }}$ June 2015; Accepted: 24 $4^{\text {th }}$ September 2015; Published: $12^{\text {th }}$ November 2015

\section{Introduction}

Introduced in therapy since the early 80's, platinum derivatives still represent a reference class of anticancer compounds. In 1845, Michele Peyrone discovered cisplatin, lately known as Peyrone's salt, whose antitumor properties have been serendipitously highlighted in 1965 by Barnett Rosenberg et al. (1). The extraordinary results of cisplatin in oncological therapy pushed researchers to continue the synthesis of platinum compounds with anticancer activity.

Until the present date, in oncological therapy there are three compounds that are being used on a large scale: Cisplatin - the first generation, Carboplatin - the second generation, and Oxaliplatin - the third generation. Other platinum derivatives that are being used on a smaller scale are Nedaplatin - approved in Japan, Lobaplatin - approved in China, and Heptaplatin - approved in the Republic of Korea (2). Platinum derivatives play an essential role in the treatment of cancers of various etiologies such as: ovarian cancer, colon cancer, stomach cancer and pulmonary cancer (3).

In terms of mechanism of action, platinum derivatives belong to the alkylating agents cat- egory. Forming intra-strand or inter-strand adducts with the cancer cell's DNA is characteristic for this class of drugs, having an affinity for guanine's $7^{\text {th }}$ position nitrogen atom. The forming of these adducts induces modifications in DNA structure, which inhibits cellular replication (4). The cis position of the ligands offers a greater stability to the drug than the trans position (5).

The efficiency of generic drugs compared to branded drugs is a debatable subject among professional healthcare providers and patients. The European Medicines Agency defines a generic drug as a "medicine that contains the same active substances as the reference medicine, and is used at the same doses to treat the same diseases. However, a generic medicine's inactive ingredients, name, appearance and packaging can be different from the reference medicine's" (6). Usually a branded drug loses about $80 \%$ of its market shares after 1 year of generic brand authorization (7). It has been observed that patients respond differently to generic and original drugs treatment and therefore the first question mark appears: "If there is no difference between the generic and original drugs, why do patients respond differently to the treatment?" and "If there are differences between the two types of 
drugs, what are they and how serious is their effect on the treatment?" Some studies already revealed a difference regarding the efficiency and the occurrence of adverse effects when using generic drugs vs. the original drug (8-13). Our study is based on the clinical observation regarding the patients overall survival and drug-free interval in which our team observed a significant drop once the generic drugs entered the hospital system. Our aim was to study the in vitro activity of oxaliplatin (L-OHP) and carboplatin (original vs. generic drugs) against several human carcinoma cell lines.

\section{Material and methods}

\section{Cell lines and cultures}

A2780 is an epithelial human ovarian carcinoma cell line and DLD-1 and HT-29 are epithelial colorectal human carcinoma cell lines, which were obtained from ECACC through Sigma Aldrich. DLD-1 and A2780 were cultivated in RPMI-1640 and HT-29 in McCoy`s 5A Modified Medium, all supplemented with Fetal Calf Serum $10 \%, 2 \mathrm{mM}$ L-glutamine and $1 \%$ penicillin-streptomycin (Sigma-Aldrich, St. Louis, MO). Experiments were performed at a $70-80 \%$ cell confluence and confirmed in at least two independent experiments unless stated otherwise.

DLD-1 and HT-29 cell lines were treated with oxaliplatin brand and two generic drugs with concentrations ranging from 0.5 to $300 \mu \mathrm{g} /$ $\mathrm{mL}$. The cells were seeded at a density of $1 \times 10^{4}$ DLD- 1 cells/well and $12 \times 10^{3}$ HT-29 cells/well using 96 -well plates. The treatment was applied after 24 hours and the cells were incubated for an additional 24 or 48 hours.

A2780 cell line was treated with two carboplatin generic drugs and the reference molecule from Santa Cruz Biotechnology, with concentrations ranging from 1 to $1000 \mu \mathrm{g} / \mathrm{mL}$. The cells were seeded at a density of $15 \times 103$ cells/well using $96-$ well plates. The treatment was applied after 48 hours and the cells were incubated for an additional 24 hours.

\section{Cytotoxicity evaluation}

The evaluation of drugs cytotoxicity was done by MTT assay. This is a colorimetric assay for assessing cell viability. It is based on the reduction of MTT (3-(4,5-dimethylthiazol-2-yl)-2,5-diphenyltetrazolium bromide) into a purple colored formazan product by the viable cells (dead cells cannot do the conversion thus they remain uncolored) (14). Absorbance was recorded with a Biotek Synergy 2 at 570nm wavelength. The half maximal inhibitory concentration (IC50) values were calculated as the concentrations corresponding to a $50 \%$ reduction of the cellular growth.

The images were taken using a Carl Zeiss Axiovert D1 microscope, 40X objective, equipped with a MRC CCD camera. After 1 hour of incubation with MTT, images were captured and analyzed with a morphometric software, AxioRel 4.8.

Statistical analysis was performed using Graph Pad Prism software program version 5.0 (San Diego, CA, USA). Statistical comparison between groups was made by one-way ANOVA (One-way analysis of variance) and by unpaired one-tailed $t$ test.

\section{Results}

\section{DLD-1 cells treated with $L-O H P$}

After 24 hours of exposure to L-OHP we found a significantly higher IC50 value for the original drug compared to the Oxaliplatin generic I $(p=0.0086)$ and Oxaliplatin generic II $(p=0.0339)$. There were no statistically significant differences between the two generics $(\mathrm{p}=$ 0.182) (Figure 1). Comparing the exposure after 48 hours of treatment, the differences were not statistically significant: oxaliplatin original vs. oxaliplatin generic $\mathrm{I}(\mathrm{p}=0.238)$ and oxaliplatin 


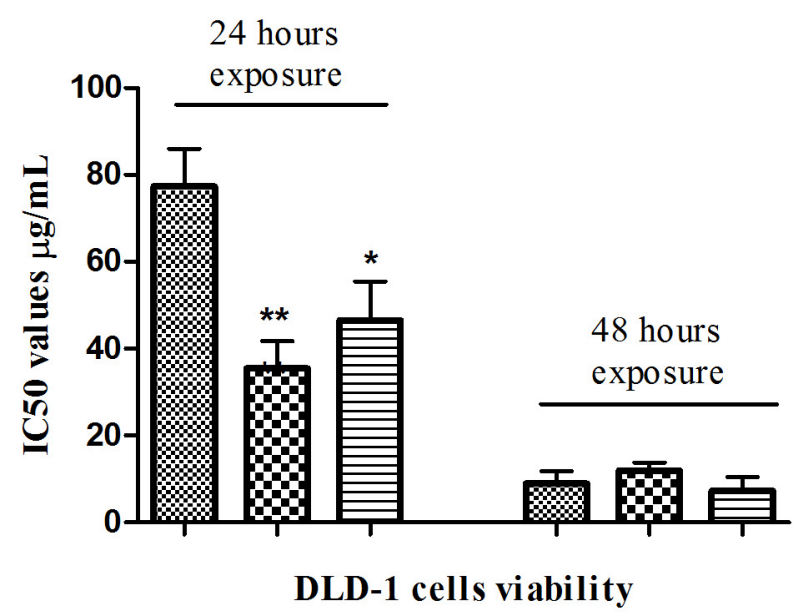

Oxaliplatin original

Exa Oxaliplatin generic I

Oxaliplatin generic II

\section{DLD-1 cells viability}

Figure 1. DLD-1 cells viability after 24 and 48 hours exposure at L-OHP brand and generics drug.

original vs. oxaliplatin generic II $(\mathrm{p}=0.364)$ but a decrease in IC50 values for the original drug was observed (Table I).

\section{HT-29 cells treated with L-OHP}

After 24 and 48 hours of exposure to L-OHP there were no statistical differences between the original and generic drugs. A slight increase in IC50 was observed for L-OHP original drug at
24 hours and a decrease in IC50 after 48 hours of treatment (Table II).

\section{A2780 cells treated with carboplatin}

Regarding the A2780 cells' response to carboplatin, no difference in IC 50 values between the reference molecule and the two generic drugs was observed after 24 hours of exposure (Table III).

Table I. DLD-1 cells IC50 values $(\mu \mathrm{g} / \mathrm{mL})$ after exposure at oxaliplatin brand and generic drugs. Values are means \pm SEM.

\begin{tabular}{lccc}
\hline DLD-1 & Oxaliplatin original & Oxaliplatin generic I & Oxaliplatin generic II \\
\hline IC50 values after 24 hours exposure & $77.403 \pm 8.656$ & $35.417 \pm 6.292$ & $46.550 \pm 8.896$ \\
\hline IC50 values after 48 hours exposure & $8.991 \pm 2.829$ & $11.940 \pm 1.880$ & $7.847 \pm 2.623$ \\
\hline
\end{tabular}

Table II. HT-29 cells IC50 values ( $\mu \mathrm{g} / \mathrm{mL})$ after exposure at oxaliplatin brand and generic drugs. Values are means \pm SEM.

\begin{tabular}{cccc}
\hline HT-29 & Oxaliplatin original & Oxaliplatin generic I & Oxaliplatin generic II \\
\hline IC50 values after 24 hours exposure & $42.670 \pm 0.140$ & $33.980 \pm 9.720$ & $38.450 \pm 6.870$ \\
\hline IC50 values after 48 hours exposure & $19.82 \pm 5.227$ & $24.14 \pm 1.374$ & $27.77 \pm 1.597$ \\
\hline
\end{tabular}

Table III. A2780 cells IC50 values $(\mu \mathrm{g} / \mathrm{mL})$ after exposure at carboplatin generic drugs and the reference molecule purchased from Santa Cruz Biotechnology. Values are means \pm SEM.

\begin{tabular}{cccc}
\hline A2780 & Carboplatin Santa Cruz Biotechnology & Carboplatin generic I & Carboplatin generic II \\
\hline $\begin{array}{c}\text { IC50 values after 24 } \\
\text { hours exposure }\end{array}$ & $227.410 \pm 16.328$ & $210.100 \pm 15.627$ & $234.640 \pm 27.150$ \\
\hline
\end{tabular}




\section{Morphology analysis}

The cells' morphology changed after the drugs' concentration increased as phase contrast images highlighted the stained cells with MTT. We observed a decrease in cells number as drug concentration increased and a decreased mitochondrial capacity to reduce MTT salt to formazan crystals with the appearance of colorless cells (Table IV and V). Signs of characteristic apoptotic changes were observed such as chromatin condensation and membrane blebbing. ( Figure 2)(15, 16).

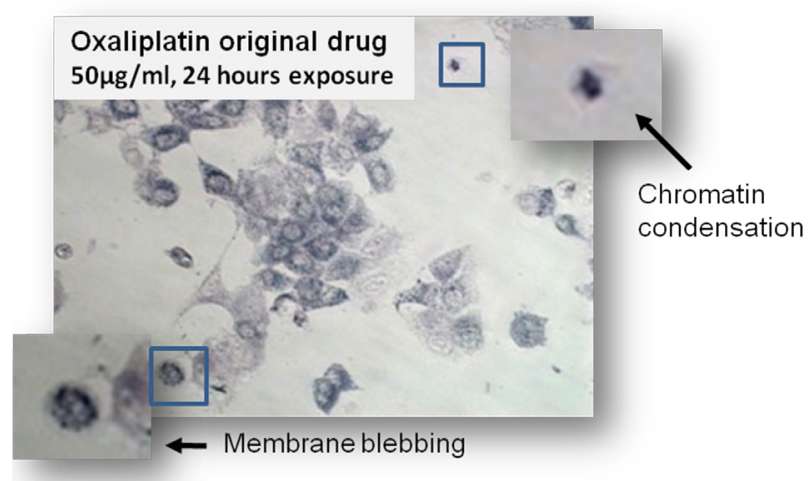

A

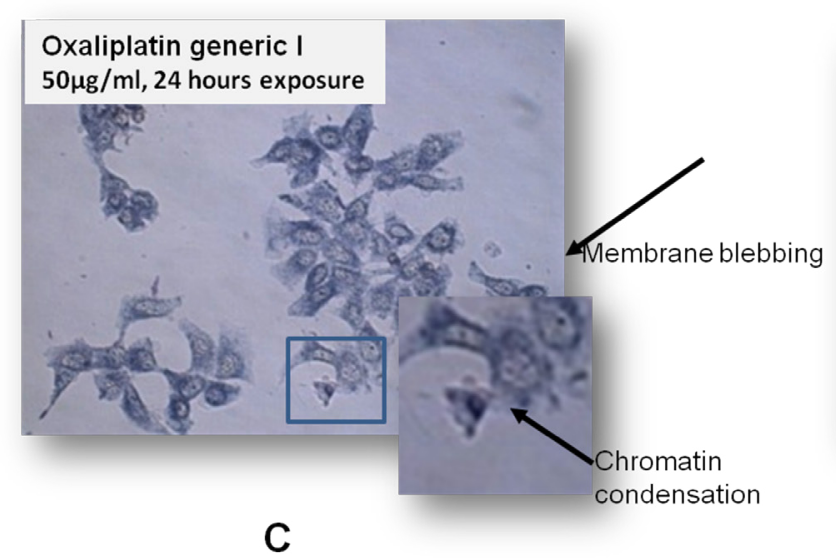

\section{Discussion}

\section{IC50 values}

Based on the IC50 values, a higher acute toxicity can be observed for the generic drugs, but when it comes to a longer exposure to the cytotoxic (48 hours), the original drug appears to be more efficient in vitro.

Also, a difference regarding the DLD-1 and HT-29 response to therapy can be observed. It appears that the HT-29 line is more resistant to oxaliplatin than the DLD-1. The IC50 values are higher in HT-29 after 48 hours of exposure to ox-

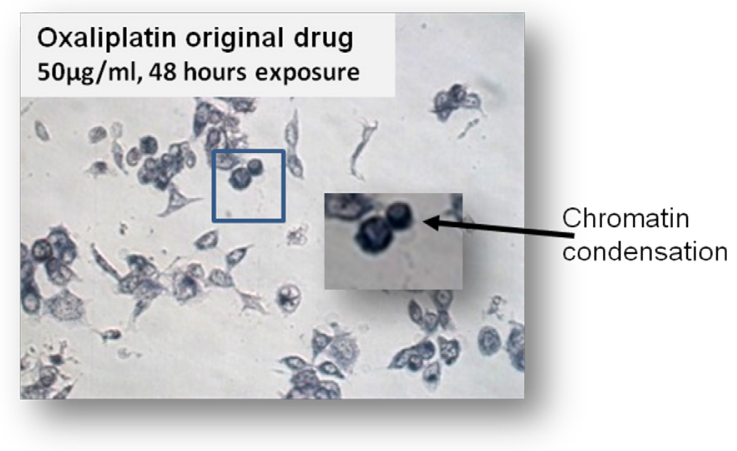

B

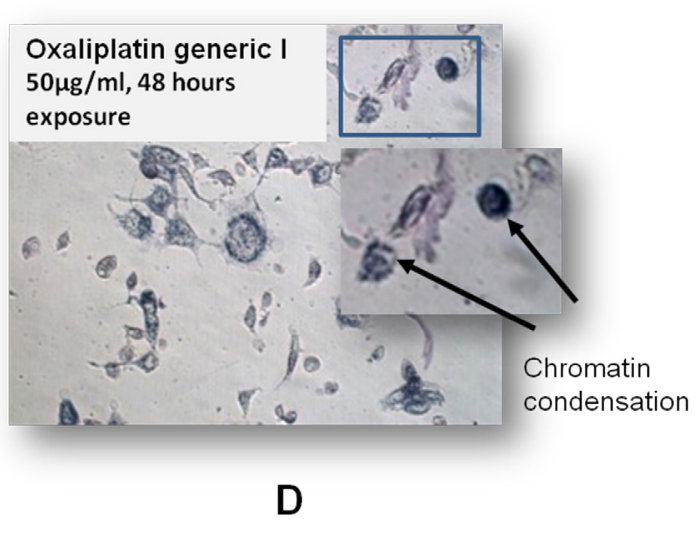

Figure 2. Morphological changes of DLD-1 cells under L-OHP original and generic I drugs 


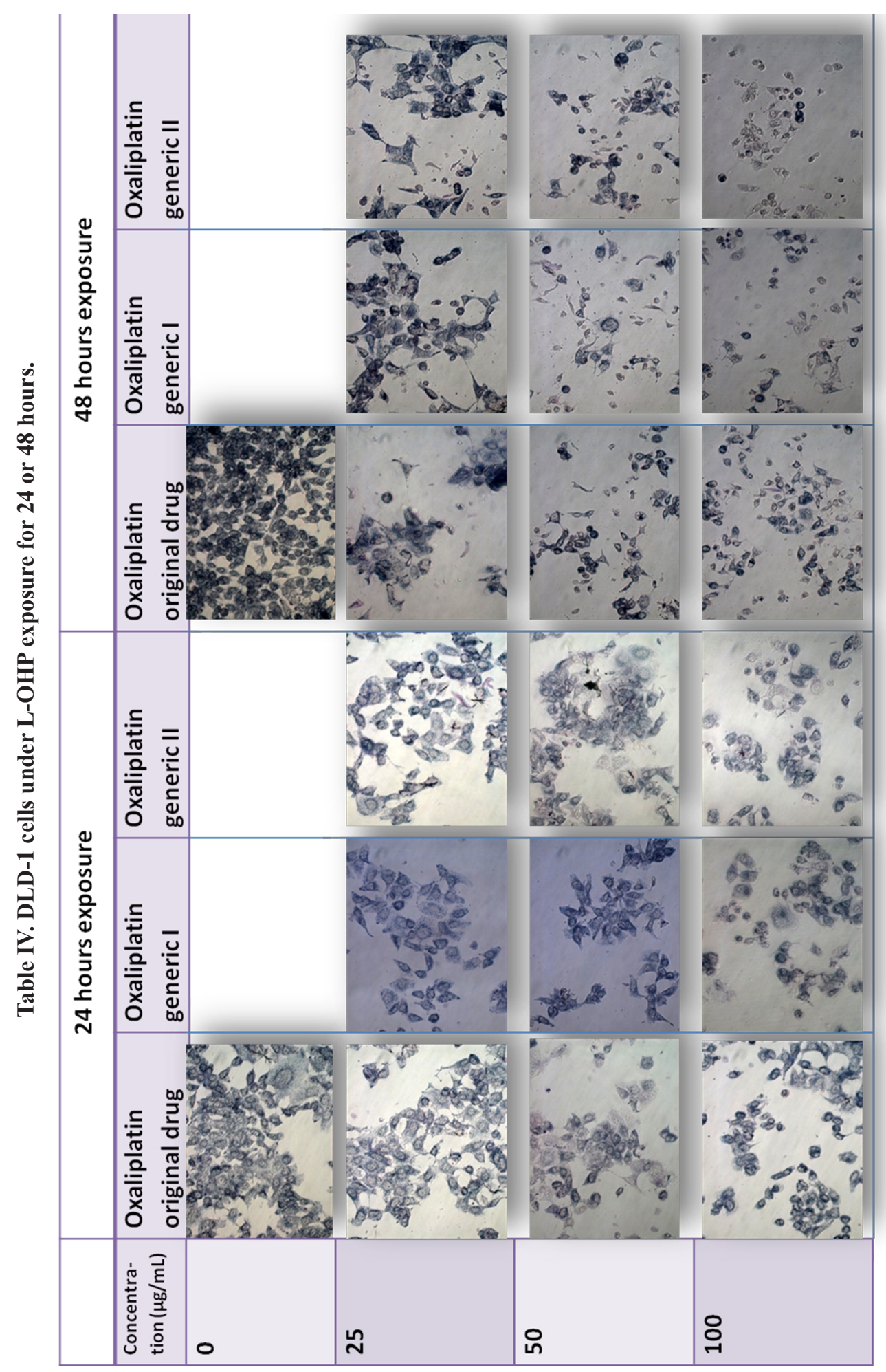




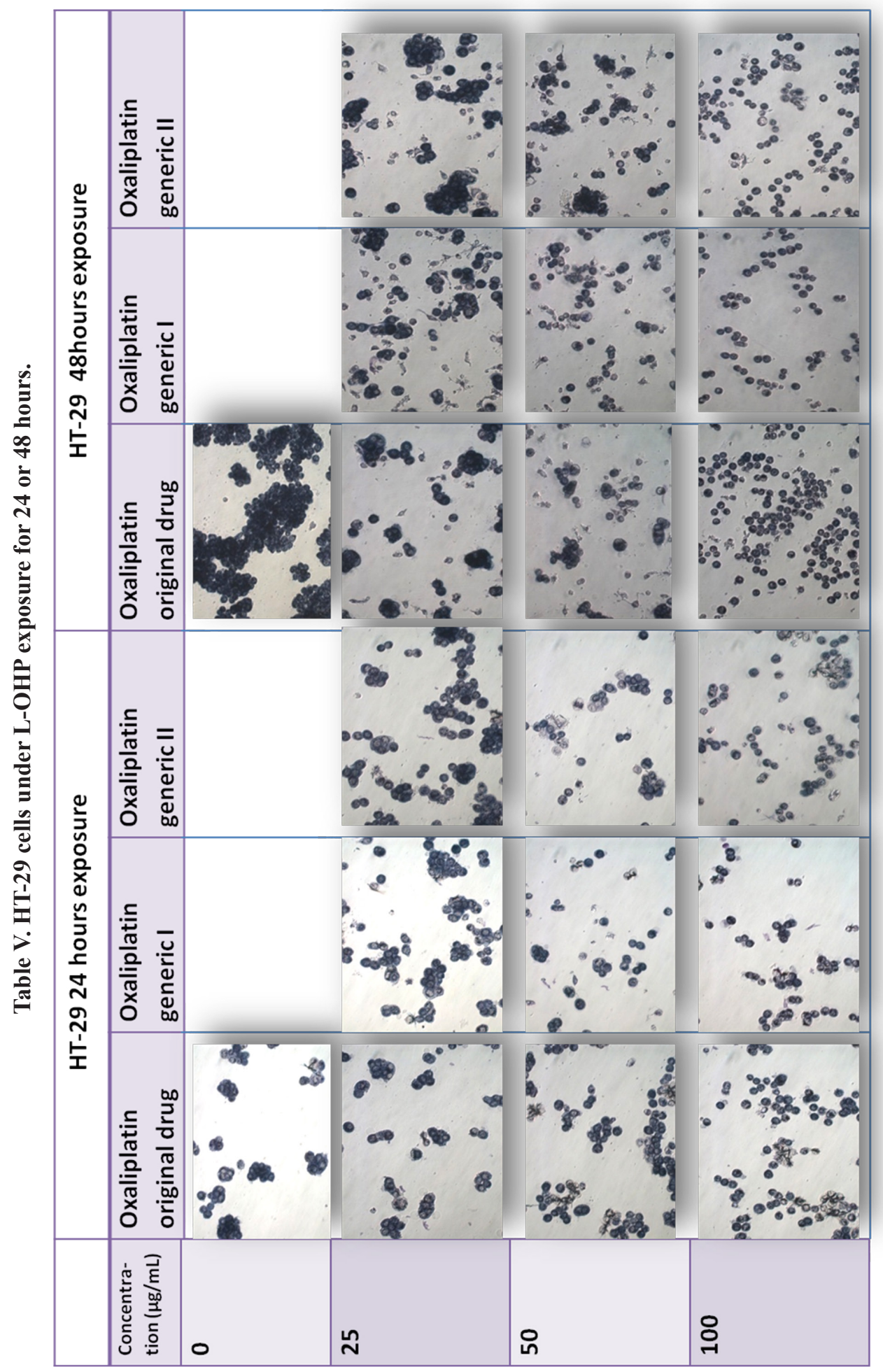


aliplatin and a slower disorganization of the cell structure can be observed, compared to DLD-1 cells (Table V). This difference was noted by other researchers. A study by Chang et al. showed that HT-29 cells were more resistant to curcumin treatment than DLD-1 cells and a study by Liou et al. showed that HT-29 cells were more resistant to arachidonic acid and $\mathrm{H} 2 \mathrm{O} 2$-induced apoptosis than DLD-1 cells $(17,18)$. Another explanation regarding the resistance of HT-29 cell line to L-OHP could be the number of CD133 positive cells, which is higher in the HT-29 cell line comparative with the DLD-1 cell line. CD133 is a marker for cancer stem cells, which are known to be responsible for the resistance to therapy, metastasis and relapse of the disease. A study by Sahlberg et al. showed that HT-29 cells had a higher expression of CD133 positive cells than the DLD-1 cells (19). This fact could influence dramatically the outcome of therapy in patients, since the treatment of colorectal cancer is not yet targeted on the tumor characteristics. Due to the fact that cancer is a heterogeneous group of cells, differences in patients' response could be the result of different chemosensitivity to therapy.

In our study, the efficiency of carboplatin generic drugs and the reference molecule from Santa Cruz Biotechnology seems to be alike, with no statistically significant differences. Regarding the mechanism of action, carboplatin induces apoptosis due to the formation of DNA adducts and other mechanisms (4). Our findings showed a higher toxicity for the L-OHP generic drugs, which could lead to the presumption that these drugs could have a higher toxicity in vivo towards the healthy cells, thus leading to an increased number of side effects. A research by Rasul et al. has shown that patients treated with generic oxaliplatin showed more side effects than the original drug-treated group (20). The differences between the original and generic drugs could also come, as a study of Gallelli et al. has shown, from their excipients - a change in the excipients list may be a cause for the differences in response to therapy and also the occurrence of allergic reactions (7).

\section{Morphology discussion}

Apoptosis is a genetically regulated form of cell death. It has a very important role, including the recognition of fetal abnormalities during intrauterine life, aging and many diseases (21). Platinum derivatives manifest their antitumor activity by inducing the apoptosis via different pathways (22). Once the apoptosis is installed, the morphology of the cell changes with the appearance of a blebbing membrane, chromatin condensation, nuclear fragmentation and formation of apoptotic bodies $(15,23)$.

DLD-1 cells are epithelial-like carcinoma cells that have an irregular shape; they grow side by side, connected as observed on the control images (cells that have not been treated). As the concentration of L-OHP increases, membrane blebbing and decreased number of viable cells (decoloration of the cells) can be observed (Table IV).

HT-29 cells have a round shape, growing in clusters, forming large spheres as can be observed in the control images (cells that have not been treated). We can observe a disorganization of the spheres as the concentration of L-OHP increases, and at high concentrations the cells are shown separately. Also, a decrease in the number of viable cells (decoloration of the cells) was observed. This highlights the increased degree of damage produced by L-OHP (Table V).

\section{Authorization procedure in Romania for generic drugs.}

In Romania, the law that regulates the status of drugs (Law 95/2006, Chapter XVII) defines a generic drug as "a drug that has the same qualitative and quantitative composition in terms of active substances and the same pharmaceutical 
form as the reference medicinal product, and whose bioequivalence with the reference medicinal product has been demonstrated through appropriate bioavailability studies". It is stipulated that if the manufacturer can prove that the drug is a generic of an original drug which is or was authorized in Romania for at least 8 years, in another state of the European Union or by a centralized procedure in the European Union, the manufacturer of the generic drug is not obliged to attach the results of the pre-clinic and clinical tests. The tests can be replaced by a review of the literature if it's considered that there are enough studies regarding the original drug. Also, the bioequivalence is tested on healthy volunteers and the absorption, distribution, metabolizing and excretion of the drug are investigated, not the therapeutic effect. All these aspects could lead to a poor verification of the efficacy of generic drugs. Therefore a generic drug may be a bioequivalent but not the therapeutic equivalent.

\section{Final remarks}

Our study`s findings showed a lower toxicity for acute exposure for the original drug, but a better activity when the time of exposure increased. Although other studies reported differences between generic and branded drugs in terms of hypersensitivity reactions, adverse effects and efficacy, we cannot extrapolate our findings to the patients. Further studies on patients are needed for a better evaluation of the efficacy of original vs. generic drugs. The question regarding the use of generic drugs remains unclear. If the manufacturers prove before the authorization that their products are equivalent to the original drugs, why are there differences? Aren't they the therapeutic equivalent of the branded drugs?

Regarding our study limitations, we can identify the lack of clinical data available before the use of generic drugs, the limited number of cell lines for testing and lack of the original carboplatin drug.

\section{Acknowledgement}

This paper was published under the frame of European Social Fund, Human Resources Development Operational Programme 2007-2013, project no. POSDRU/159/1.5/S/138776.

We acknowledge the financial support of Romanian National Council for Scientific Research in Higher Education Grant no PN-II-IDPCE-2011-3-1057, contract no 250/2011.

\section{Abreviations}

IC50 - the half maximal inhibitory concentration

L-OHP - oxaliplatin

MTT - 3-(4,5-dimethylthiazol-2-yl)-2,5-diphenyltetrazolium bromide

\section{References}

1. Bertini I, editor. Bioinorganic chemistry. Mill Valley, Calif: University Science Books; 1994. 611 p.

2. Wheate NJ, Walker S, Craig GE, Oun R. The status of platinum anticancer drugs in the clinic and in clinical trials. Dalton Trans. 2010;39(35):8113. DOI: 10.1039/ c0dt00292e

3. Parel M, Ranchon F, Nosbaum A, You B, Vantard N, Schwiertz V, et al. Hypersensitivity to oxaliplatin: clinical features and risk factors. BMC Pharmacol Toxicol. 2014;15(1):1. DOI: 10.1186/2050-6511-15-1

4. Desoize B, Madoulet C. Particular aspects of platinum compounds used at present in cancer treatment. Crit Rev Oncol Hematol. 2002 Jun;42(3):317-25. DOI: 10.1016/S1040-8428(01)00219-0

5. Boulikas T, Vougiouka M. Cisplatin and platinum drugs at the molecular level. (Review). Oncol Rep. 2003 Dec;10(6):1663-82. DOI: 10.3892/or.10.6.1663

6. European Medicines Agency. http://www.ema.europa. eu/ema/index.jsp?curl=pages/special_topics/document_listing/document_listing_000335.jsp\&mid=WC0b01ac0580514d5c.

7. Gallelli L, Mumoli L, Palleria C, Piro B, Russo E, 
Vasapollo P, et al. Safety and efficacy of generic drugs with respect to brand formulation. J Pharmacol Pharmacother. 2013;4(5):110. DOI: 10.4103/0976500X.120972

8. Vetchy D, Vetcha M, Rabiskova M, Gryczova E, Bartosikova L. Comparison in vitro felodipine release rate from the original versus generic product with controlled release of the drug. Med Kaunas Lith. 2007;43(4):32631.

9. Poirier E, Desbiens C, Poirier B, Hogue J-C, Lemieux J, Doyle C, et al. Comparison of serious adverse events between the original and a generic docetaxel in breast cancer patients. Ann Pharmacother. 2014 Apr;48(4):447-55. DOI: 10.1177/1060028013514941

10. Tange M, Yoshida M, Nakai Y, Uchida T. Comparison between original and generic versions of ceftriaxone sodium preparation for injection: compatibility with calcium-containing product. Chem Pharm Bull (Tokyo). 2012;60(4):429-34. DOI: 10.1248/cpb.60.429

11. Shimatani T, Inoue M, Kuroiwa T, Xu J, Mieno H, Tazuma S. Acid-suppressive effects of generic omeprazole: comparison of three brands of generic omeprazole with original omeprazole. Dig Liver Dis Off J Ital Soc Gastroenterol Ital Assoc Study Liver. 2006 Aug;38(8):554-9. DOI: 10.1016/j.dld.2006.01.032

12. Minzi OMS, Marealle IA, Shekalaghe S, Juma O, Ngaimisi E, Chemba M, et al. Comparison of bioavailability between the most available generic tablet formulation containing artemether and lumefantrine on the Tanzanian market and the innovator's product. Malar J. 2013;12:174. DOI: 10.1186/1475-2875-12-174

13. Gasser UE, Fischer A, Timmermans JP, Arnet I. Pharmaceutical quality of seven generic Levodopa/Benserazide products compared with original Madopar ${ }^{\circledR} /$ Prolopa ${ }^{\circledR}$. BMC Pharmacol Toxicol. 2013;14(1):24. DOI: $10.1186 / 2050-6511-14-24$

14. Sittampalam GS, Coussens NP, Nelson H, Arkin M, Auld D, Austin C, et al., editors. Assay Guidance Manual [Internet]. Bethesda (MD): Eli Lilly \& Company and the National Center for Advancing Translational Sciences; 2004 [cited 2015 May 1]. Available from:
http://www.ncbi.nlm.nih.gov/books/NBK53196/

15. Vanden Berghe T, Grootjans S, Goossens V, Dondelinger Y, Krysko DV, Takahashi N, et al. Determination of apoptotic and necrotic cell death in vitro and in vivo. Methods San Diego Calif. 2013 Jun 1;61(2):11729. DOI: $10.1016 /$ j.ymeth.2013.02.011

16. Krysko DV, Vanden Berghe T, D'Herde K, Vandenabeele P. Apoptosis and necrosis: Detection, discrimination and phagocytosis. Methods. 2008 Mar;44(3):20521. DOI: $10.1016 /$ j.ymeth.2007.12.001

17. Chang Y-J, Huang C-Y, Hung C-S, Chen W-Y, Wei P-L. GRP78 mediates the therapeutic efficacy of curcumin on colon cancer. Tumor Biol. 2015 Feb;36(2):633-41. DOI: $10.1007 / \mathrm{s} 13277-014-2640-3$

18. Liou J-Y, Aleksic N, Chen S-F, Han T-J, Shyue S-K, Wu KK. Mitochondrial localization of cyclooxygenase-2 and calcium-independent phospholipase A2 in human cancer cells: implication in apoptosis resistance. Exp Cell Res. 2005 May 15;306(1):75-84. DOI: 10.1016/j. yexcr.2005.01.011

19. Sahlberg SH, Spiegelberg D, Glimelius B, Stenerlöw B, Nestor M. Evaluation of Cancer Stem Cell Markers CD133, CD44, CD24: Association with AKT Isoforms and Radiation Resistance in Colon Cancer Cells. Yeudall A, editor. PLoS ONE. 2014 Apr 23;9(4):e94621.

20. Rasul KI, Kamal AS, Al-Najjar NM, Oculalan MH. Is there a Diference between Brand and Generic Oxaliplatin? Cancer Clin Oncol [Internet]. 2012 Jun 18 [cited 2015 Apr 30];1(2). Available from: http://www.ccsenet. org/journal/index.php/cco/article/view/18157

21. Renehan AG, Booth C, Potten CS. What is apoptosis, and why is it important? BMJ. 2001 Jun 23;322(7301):15368. DOI: $10.1136 / \mathrm{bmj} .322 .7301 .1536$

22. Florea A-M, Büsselberg D. Cisplatin as an Anti-Tumor Drug: Cellular Mechanisms of Activity, Drug Resistance and Induced Side Effects. Cancers. 2011 Mar 15;3(4):1351-71. DOI: 10.3390/cancers3011351

23. Henry CM, Hollville E, Martin SJ. Measuring apoptosis by microscopy and flow cytometry. Methods. 2013 Jun;61(2):90-7. DOI: 10.1016/j.ymeth.2013.01.008 